
ДО ПИТАННЯ ПІДГОТОВКИ ФАХІВЦІВ

Кравченко Оксана Олексіївна, доктор педагогічних наук, доцент, професор кафедри соціальної педагогіки та соціальної роботи, декан факультету соціальної та психологічної освіти Уманський держсавний педагогічний університет імені Павла Тичини

(20301, Украӥна, Умань, вулиця Садова, 28, e-mail: okskravchenko@ukr.net)

Анотація. Стаття присвячення питанню соціальної роботи з жінками із сільської місцевості, які зазнали насилля, а також висвітленню підходів до підготовки фахівців, які надають соціальні послуги цій категорії населення. Встановлено, що гендерна політика грунтується не лише на основі міжнародних нормативно-правових актів, ратифікованих Україною, а й регулюється національними нормативно-правовими актами щодо рівноправності між жінками і чоловіками. Важливим напрямом гендерної політики є забезпечення рівних прав і можливостей жінок із сільської місцевості, у тому числі, і реалізація їхніх прав людини. Разом з тим, жінки в сільській місцевості уразливіші до гендерно-обумовленого насильства, ніж жінки, які живуть у містах, що потребує спеціально розробленої програми їхньої соціально-психологічної реабілітації. За результатами з'ясування змісту і спрямованості соціальної роботи з жінками, вивчення регіонального досвіду діяльності соціальних служб з жінками, розкриття специфіки підготовки майбутніх соціальних працівників до роботи з цією категорією громадян, розроблено рекомендації стосовно підвищення якості надання соціальних послуг жінкам - жертвам домашнього насилля.

Ключові слова: соціальна робота, жінки, гендер, сільська місцевість, підготовка майбутніх соціальних працівників.

\title{
SOCIAL WORK WITH WOMEN FROM AGRICULTURAL LOCATIONS, WHICH WOULD BROUGHT: GENERAL PRINCIPLES AND QUESTIONS FOR PROFESSIONAL PREPARATION
}

\section{(C) 2017}

Kravchenko Oksana Alekseevna, doctor of pedagogical sciences, Associate Professor, professor of the department of Social Pedagogy and social, Dean of the Faculty of Social and Psychological Education Uman State Pedagogical University named Pavlo Tychyna

(20301, Ukraine, Uman, Sadova street,28, e-mail: okskravchenko@ukr.net)

Abstract. An article devoted to the issue of social work with women from rural areas that were violent, as well as coverage of approaches to training specialists providing social services to this category of population. It is established that gender policy is based not only on international normative legal acts ratified by Ukraine, but also regulated by national legal acts on equality between women and men. An important area of gender policy is the provision of equal rights and opportunities for women from rural areas, including, the realization of their human rights. At the same time, women in rural areas are more vulnerable to gender-based violence than women living in cities that require a specially designed program for their social and psychological rehabilitation. As a result of the clarification of the content and focus of social work with women, the study of the regional experience of social services with women, the disclosure of the specifics of the training of future social workers to work with this category of citizens, recommendations for improving the quality of social services for women victims of domestic violence have been developed.

Keywords: social work, women, gender, rural areas, preparation of future social workers.

Постановка проблеми в загальному вигляді та ї̈ зв'язок із важливими науковими чи практичними завданнями. 62 сесія Комісії ООН зі статусу жінок (КСЖ62), головного глобального міжурядового органу, чия діяльність присвячена виключно просуванню гендерної рівності та розширенню прав і можливостей жінок, відбулася в штаб-квартирі Організації Об'єднаних Націй у Нью-Йорку з 12 по 23 березня за темою «Проблеми та перспективи досягнення гендерної рівності та розширення прав і можливостей жінок та дівчат у сільській місцевості».

Комісія була створена ЕКОСОР у 1946 р. $з$ повноваженнями щодо підготовки рекомендацій із захисту прав жінок у політичній, економічній, громадській, соціальній та освітніх сферах. Комісія також відповідає за моніторинг, огляд і оцінку досягнутого прогресу та проблеми, що виникають у ході здійснення Пекінської декларації та Платформи дій 1995 р. і підсумків 23-ї спеціальної сесії Генеральної Асамблеї 2000 р. на всіх рівнях, а також підтримку гендерної проблематики. Крім того, Комісія робить внесок у подальшу діяльність за підсумками Порядку денного сталого розвитку на період до 2030 р., 3 тим, щоб прискорити реалізацію гендерної рівності та розширення прав і можливостей жінок та дівчат.

62 сесія, проведена у Міжнародний жіночий день, стала ще одним приводом привернути увагу до прав та активної діяльності жінок у сільській місцевості та слушною нагодою для системи ООН та іiі партнерів 3 уряду, парламенту, громадянського суспільства та міжнародних організацій спільно обговорити це питання та взяти на себе зобов'язання вжити заходів, які змінять життя жінок на краще [10].
Зокрема, державна політика, нині, орієнтується на створення рівних можливостей для жінок і чоловіків, при цьому вона проводиться з урахуванням міжнародних документів, підписаних Україною. Це, зокрема, Загальна декларація прав людини, 1948 р.; Міжнародний пакт про громадські та політичні права, 1966 р.; Статут Організації Об’єднаних Націй, 1945 р.; Декларація про ліквідацію дискримінації у відношенні жінок, 1967 р.; Конвенція про боротьбу 3 торгівлею людьми та 3 експлуатацією проституції третіми особами, 1949 р.; Конвенція про ліквідацію усіх форм дискримінації щодо жінок, 1979 р.; Конвенція про захист прав людини і основоположних свобод, 1950 р.; Пекінська декларація, 1995 р. тощо.

Гендерна політика грунтується не лише на основі міжнародних нормативно-правових актів, ратифікованих Україною, а й регулюється національними нормативноправовими актами щодо рівноправності між жінками і чоловіками.

Аналіз останніх досліджень $i$ публікацій, в яких розглядалися аспекти иієї проблеми $і$ на яких обтрунтовується автор; виділення невирішених раніше частин загальної проблеми За роки незалежності прийнято низку стратегічних документів, де враховано гендерний аспект: Розпорядження Кабінету Міністрів України «Про затвердження плану заходів з реалізації Національної стратегії у сфері прав людини на період до 2020 року»; Розпорядження Кабінету Міністрів України «Про затвердження національного плану дій 3 виконання резолюції Ради Безпеки України ООН 1325 «Жінки, мир, безпека»; Національна стратегія у сфері прав людини та план дій з іiі реалізації; Стратегія подолання бідності та План дій з їі реалізації; Концепція реформування державного управління; Міністерством 
освіти і науки розроблено проект Стратегії «Освіта: гендерний вимір 2020»; Національний план дій з виконання Резолюції Ради Безпеки ООН № 1325 «Жінки, мир, безпека», затверджений розпорядженням Кабінету Міністрів України у 2016 році, консолідує дії державних інституцій і суспільства щодо активізації участі жінок у встановленні миру, наданні допомоги, захисті та реабілітації постраждалих від насильства; у квітні 2017 року Урядом затверджено розроблену Мінсоцполітики Концепцію державної соціальної програми забезпечення рівних прав та можливостей жінок і чоловіків на період до 2021 року.

Формування иілей статті (постановка завдання). Мета статті - на основі аналізу нормативно-правових засад схарактеризувати специфіку соціальної роботи 3 жінками.

Виклад основного матеріалу дослідження з повним обтрунтуванням отриманих наукових результатів. Цей аспект є основним фактором досягнення гендерної рівності та Цілей сталого розвитку: «Сталого розвитку не можна досягти без гендерної рівності та розширення прав і можливостей усіх жінок та дівчат. Метою Порядку денного сталого розвитку є дотримання тих прав жінок і дівчат з сільської місцевості, які $є$ необхідними для забезпечення їм засобів до існування, добробуту та здатності пристосовуватися до нових умов, зокрема прав на: землю і захист прав власності; їжу та харчування відповідної якості та кількості; життя, вільне від усіх форм насильства, дискримінації та шкідливих практик; найвищий можливий стандарт здоров'я, зокрема сексуальне та репродуктивне здоров'я й права на нього; якісну, фінансово прийнятну та доступну освіту протягом життя [4].

Ратифікувавши Конвенцію ООН з ліквідації всіх форм дискримінації щодо жінок Україна, зокрема, взяла зобов'язання: брати до уваги особливі проблеми, 3 якими стикаються жінки, що проживають у сільській місцевості, і роль, яку вони відіграють у забезпеченні економічного добробуту своїх сімей, в тому числі їхня діяльність у нетоварних галузях господарства; вживати усіх відповідних заходів щодо забезпечення застосування положень Конвенції до жінок, які проживають у сільській місцевості [8].

Ратифікувавши Стамбульську декларацію із населених пунктів (1996), українська держава поставила серед пріоритетів питання комплексного розвитку не тільки міст, а й сільської місцевості, визнала «особливі потреби жінок, дітей і молоді у стабільних, здорових і безпечних умовах життя» (стаття 7). У документі зазначено: «Розвиток сільських і міських районів носить взаємозалежний характер. Крім поліпшення умов життя в містах, ми також повинні прагнути до забезпечення адекватної інфраструктури, громадських послуг і можливостей працевлаштування в сільських районах $з$ метою підвищення їх привабливості, створення комплексної мережі населених пунктів i зведення до мінімуму міграцію населення із сільських районів у міста» (стаття 6). Також зауважено про забезпечення повної участі усіх жінок і чоловіків (у тому числі, у сільській місцевості) у економічному і політичному житті держави [8].

Конституція України (від 28 червня 1996 року) у Розділі II «Права, свободи та обов'язки людини і громадянина» ст. 24 гарантує громадянам рівні конституційні права і свободи, «не може бути привілеїв чи обмежень за ознаками раси, кольору шкіри, політичних, релігійних та інших переконань, статі, етнічного та соціального походження, майнового стану, місця проживання, за мовними або іншими ознаками».

Рамкова програма партнерства між Урядом України та Організацією Об'єднаних Націй (2018-2022 рр.) визнає, що жінки в сільській місцевості є групою населення, яка часто залишається поза увагою та виключена 3 процесів розвитку, відновлення та гуманітарної діяльності. Тому система ООН визначає жінок у сільській 10 місцевості як одну 3 ключових цільових груп для своїх заходів, а також, спираючись на взаємодоповнюваність мандатів різних структур системи ООН, працює над вирішенням проблем, 3 якими стикаються жінки в сільській місцевості в Україні.

Актуальність проблеми забезпечення рівних можливостей сільських жінок обумовлена як тим фактом, що кожна третя жінка в Україні мешкає в сільській місцевості, так і результатами статистичних досліджень: $48 \%$ жінок, які мешкають у сільській місцевості, не мають доступу до медичних послуг; 36 \% жінок у сільській місцевості не беруть участі в прийнятті рішень у своїх громадах; $67 \%$ жінок у сільській місцевості не мають вдома доступу до мережі Інтернет; середня місячна заробітна плата жінок, які зайняті в сільському господарстві, рибальстві, лісовому господарстві та суміжних галузях, становить 85,5 \% від заробітної плати чоловіків; 32 \% не мають доступу до питної води вдома; $21 \%$ жінок у сільській місцевості мають банківський рахунок; внутрішньо переміщені жінки в сільській місцевості стикаються з багатьма проблемами: відповідно, рівень зайнятості серед жінок-ВПО, які живуть у селах, на 17 \% нижчий, ніж серед жінок-ВПО, які проживають у великих містах; більш того, 36 \% жінокВПО у сільській місцевості є головами домогосподарств та переважно залежать від пенсії (42 \%) і соціальної допомоги (32\%) [10].

Як показують статистичні дані, наведені вище, жінки та дівчата в сільській місцевості зазнають дискримінації щодо доступу до процесів прийняття рішень, працевлаштування, охорони здоров'я, освіти та інших базових послуг.

Це підтверджується результатами «Комплексного дослідження становища жінок, які проживають у сільській місцевості» (2015), поведеного ПРООН в Україні спільно з Секретаріатом Уповноваженого Верховної Ради України з прав людини. Дослідження стосувалося широкого кола питань, таких, як внесок жінок у розвиток сільських територій та численні складнощі, 3 якими вони зіштовхуються. Зокрема, аналіз охоплює такі права жінок, як участь у процесі розробки планів розвитку громади; доступ до закладів медичного обслуговування та користування програмами соціального забезпечення; одержання формальної та неформальної освіти; доступ до громадських послуг i консультативних служб; створення кооперативів; участь в усіх формах колективної діяльності; користування сільськогосподарськими кредитами та позиками, системами збуту; право на належні умови життя, зокрема, на належні житлові умови, санітарні послуги, забезпечення електроенергією та водопостачанням [8].

Результати дослідження доводять, що становище жінок, які проживають у сільській місцевості, значно гірше, ніж становище сільських чоловіків та жителів міст у багатьох із зазначених сфер, а також те, що жінки, які проживають у сільській місцевості, більше за інших страждають від бідності та соціальної ізоляції.

Водночас це питання має бути в полі зору фахівців закладів соціальної сфери в умовах децентралізації, зокрема щодо доступу до соціальних послуг жінок із числа населення, яке проживає або буде проживати в ОТГ в тих випадках, коли це громади сільського типу: виявлення, осіб, які перебувають у складних життєвих обставинах; визначення потреб у соціальних послугах; організація і надання соціальних послуг тим, хто цього потребує; консультування та інформування мешканців громади щодо надання всіх видів соціальної допомоги; прийом заяв та необхідних документів про надання допомоги тощо.

Проведені міжнародні аналітичні дослідження засвідчують, що розширення прав і можливостей жінок та дівчат у сільській місцевості і дотримання їхніх прав людини та гендерної рівності $є$ фактором не тільки добробуту окремих осіб, родин та сільських громад, але й Scientific Vector of the Balkans. 2017. № 1 
загальної економічної ефективності, враховуючи значний відсоток жінок серед працівників сільського господарства України.

Тим паче, що Комітет з ліквідації всіх форм дискримінації щодо жінок рекомендував Україні вдосконалити інфраструктуру в сільській місцевості та розробити політику боротьби 3 бідністю серед жінок у сільській місцевості для забезпечення їхнього доступу до правосуддя, освіти, житла, офіційної зайнятості, розвитку навичок та можливостей навчання, можливостей отримувати дохід та мікрокредитування, володіння та користування землею, враховуючи їхні особливі потреби та 3 особливою увагою до негативного впливу конфлікту на жінок у сільській місцевості [10].

Разом 3 тим, Комітет рекомендував розглядати жінок не тільки як постраждалих або отримувачів допомоги, але й як активних учасниць розробки та реалізації таких політик. Загалом жінкам із сільської місцевості в глобальному вимірі надається надзвичайно важлива роль у підтриманні та поліпшенні умов життя в сільських районах, а також зміцненні сільських громад.

Водночас жінки в сільській місцевості уразливіші до гендерно-обумовленого насильства, ніж жінки, які живуть у містах. Відповідно, відсоток жінок у сільській місцевості, які коли-небудь були в шлюбі та зазнали фізичного та (або) сексуального насильства, скоєного партнером, становить $17 \%$, а міських жінок- $14 \%$. Однак $55 \%$ жінок у сільській місцевості не повідомляють про випадки домашнього насильства [10].

В Україні відбуваються перші спроби запровадження й реалізації певних моделей роботи щодо попередження або усунення насилля в сім'ї: превентивної, навчальнотренінгових програм, роботи з правоохоронними органами, організації притулків для жінок, кризових консультативних центрів (очних та заочних), центрів реінтеграції, груп взаємопідтримки чи самодопомоги, психотерапевтичних програм (індивідуальних та групових).

Водночас саме проблема насильства над жінками $\epsilon$ причиною таких глобальних явищ, як безпритульність дітей; зростання кількості розлучень; формування насильницького менталітету нації; жебракування; втрата загальнолюдських цінностей, любові та взаєморозуміння; а також виступає однією з передумов скоєння злочинів у суспільстві.

Проаналізувавши вище перелічені ознаки жінокжертв сімейного насилля, у корекцію негативних станів потрібно включати:

- соціальну роботу з налагодження зв'язків;

- педагогічну роботу: навчання таким навичкам, як позитивне спілкування (вирішення конфліктів, адекватне висловлювання), адекватне мислення і ставлення до себе, прийняття рішень та психологічного захисту, сприяння підвищенню рівня самооцінки жінки;

- психологічну роботу зі зняття відчуття провини, емоційної та фізичної релаксації.

Детальніше розглянемо перший напрям - соціальної роботи, який виступає одним із дійових інструментів 3 розв'язання актуальних проблем українського жіноцтва. Соціальна робота здійснюється соціальними службами в регіоні, зокрема службами у справах дітей, сім'ї та молоді. Здійснювані в процесі соціальної роботи цими службами систематичні, різноманітні заходи спрямовані на те, щоб полегшити адаптацію (пристосування) жінки, яка потребує допомоги, до суспільних норм, допомогти їй розвинути, реалізувати і реабілітувати життєві сили, забезпечити гідне існування і самоутвердження.

Основу сімейного неблагополуччя здебільшого становлять матеріальні труднощі; алкоголізм, пияцтво; безробіття батьків; труднощі підліткового віку дітей; непрацездатність; конфлікт між членами сім’і; різні види насильства. Рівень забезпечення і виховання дітей у таких сім'ях не відповідає життєво необхідним вимогам, що, в свою чергу, накладає відбиток на їхній розвиток та поведінку.
3 метою надання своєчасної допомоги сім'ям, які потрапили у складні життєві обставини та не в змозі їх самостійно подолати доцільно працівниками соціальних центрів щотижня відвідувати сім’ї вище зазначеної категорії та проводити оцінку потреб сімей, за результатами яких надавати сім'ям 3 дітьми соціальні послуги.

3 батьками (у тому числі, 3 жінками) доцільно постійно проводити інформаційно-роз'яснювальна роботу щодо профілактики вживання спиртних напоїв, ведення здорового способу життя, попередження виникнення насильства у сім'ях, виконання належних батьківських обов'язків, дотримання санітарногігієнічних умов проживання, раціонального використання державної соціальної допомоги на дітей тощо.

3 метою надання якісних соціальних послуг жінкам важливою постає питання підготовки майбутніх соціальних працівників у цьому контексті. Зокрема, потребує посиленої уваги формування професійних компетентностей щодо рівня поінформованості студентської молоді про поняття гендеру, соціальні проблеми жінок та їх способи вирішення.

Щодо зазначеного було проведено дослідження на базі Уманського державного педагогічного університету імені Павла Тичини серед студентів, які навчаються за спеціальністю «Соціальна робота».

Студентам було запропоновано анкету «Що я знаю про проблеми жінок» без попередньої бесіди, орієнтуючись лише на знання.

У дослідженні брали участь 35 студентів: 18 студентів четвертого курсу спеціальності та 17 студентів першого курсу. Кількість заповнених анкет за статтю також різнилася і домінувальною виявилась у зацікавленості в проблемі - жіноча стать, яка склала майже дві третини опитаних.

Просте запитання з анкети «Хто для Вас є жінка?» показало різне ставлення до представниць цієї статі 3 боку юнаків та дівчат. Так, юнаки першого курсу означили жінку без нав'язливих гендерних штампів, яку мають можливість спостерігати у повсякденному житті (Богдан К.: «Жінка - це мати, робітник»); юнаки четвертого курсу - навпаки, виступили у своїх відповідях, враховуючи головні гендерні ознаки обох статей, натякаючи на свою пріоритетність у фізичному розвитку (Рустам Д.: «Жінка - це слабка стать», Микола Ж.: «Жінка - це тендітна особа жіночого роду, ніжна», Дмитро Р.: «Жінка - берегиня сім'ї, важлива складова суспільства»).

Дівчата, незалежно від віку, відповіли, як дійсні представниці цієї статі, з урахуванням гендерних складових (Владислава $€$.: «Жінка - початок нового життя», Вікторія К.: «Жінка - це кохана, мати, дочка, сестра, бабуся»), більш по-філософськи відповіли четвертокурсниці (Валерія В.: «Жінка - це запрошення до щастя!», Наталія П.: «Жінка - це джерело любові, піклування та краси»).

Про проблеми жінок студенти давали різні відповіді, серед яких можна виділити: безробіття, здоров'я, шлюб, безпліддя, алкоголізм, порушення психіки (за відповідями першокурсників); чоловіки, гендерна нерівність, насильство в сім'і, приниження, недооцінення можливостей жінки, стреси, вікові зміни, побутові проблеми, ПМС, вага, тощо (за відповідями четвертокурсників, причому на останні п’ять причин вказали хлопці).

Однотипно на запитання анкети «Хто допомагає вирішувати проблеми жінок?» відповіли студенти першого курсу. Їхніми відповідями були: «Чоловіки», «Друзі», «Рідні», «Близькі люди», інколи «Психологи». Студенти четвертого курсу відповіли 3 більшою поінформованістю щодо специфіки своєї майбутньої діяльності, що позитивно характеризує навчально-виховний процес на базі дослідження. Їхніми відповідями були: «Центри допомоги жінкам, які опинились у складній ситуації» (Інна Г.); «Психологи, лікарі, рідні 
люди» (Оксана Л.); «Місцеві органи охорони життя і здоров’я» (Дмитро П.).

Вразили відповіді студентів, які неоднозначно виразили своє ставлення до поняття «гендерної рівності» в нашій країні. Відсотків 80 відповіли «нейтрально» , «50 на 50» або «байдуже» на гендерну рівність між чоловіком та жінкою, а 10 \% взагалі дали відповідь «негативно», що доводить те, що студентами неоднозначно сприймається інформація про гендерну рівність в нашій країні.

Про це свідчать і відповіді студентів перших та четвертих курсів на запитання: «Як би Ви особисто здійснювали гендерну рівність?» 90 \% опитуваних відповіли, що не знають. Лише поодинокі відповіді старшокурсників порадували осмисленістю та правильністю думки: (Ростислав М.: «Почав би з себе. Ставився до всіх би однаково та виховував би дітей!», Артем Р.: «Надав би рівних прав і чоловікові і жінці»).

Наступним було питання про ставлення молоді (зокрема досліджуваної) до засуджених жінок, адже одним iз напрямів роботи 3 жінками в регіональних центрах соціальних служб для дітей, сім'ї та молоді $є$ робота 3 умовно засудженими жінками, яка здійснюється у формі профілактичних бесід, консультацій, реабілітації тощо і знову відкриває у відповідях студентів реалії сьогодення.

Тож відповіді розподілилися у такому порядку: 7 студентів відповіли, що їм «байдуже» або «все одно», 6 - «нормально», 5 - «негативно», решта студентів проявили невизначеність, висловлюючи свою думку приблизно у такому контексті: «Залежить від злочину» або «Дивлячись яка ситуація склалась 3 жінкою».

Продовжуючи аналіз відповідей студентів різних вікових категорій про проблеми засуджених жінок, серед юнаків та дівчат четвертого курсу, у відповідях наступного питання в анкеті виявився неоднозначний гендерний аспект. Причому юнаки проявили гендерну рівність досить категорично. Дівчата виявили більшу поблажливість до засуджених жінок, враховуючи природу існування жінки або проектуючи це на себе (проявляють рефлексію). Запитання було таким: «Чи повинні жінки відбувати покарання, як чоловіки?». У співвідношенні «Так» / «Ні»: юнаки - 95 \% / 5 \%; дівчата - 40 \% / 60 \%. Студенти першого курсу проявили більшу лояльність до жінок, які вчинили злочин («Має існувати виключення до жінок за станом здоров'я» (Вікторія); «Дивлячись на те, який злочин вони вкоїли» (Владислава)).

Торкаючись наступної проблеми жінок, проблеми насилля, яка щодо жінок набуває зростаючої тенденції в суспільстві, студенти мали виразити свою думку на рахунок розуміння поняття «насилля над жінками в сім’і». Жоден курс будь-якої дисципліни першого курсу зі спеціальності «Соціальна робота» не передбачає ознайомлення студентів 3 такою проблемою. У результаті цього студенти означеного курсу на запитання «Як Ви розумієте поняття «насилля над жінками в сім'ї»?, відповіли однозначно, - «коли чоловік б’є жінку» i звернутися за допомогою порадили до подруги або до поліції. Студенти ж старшого курсу спеціальності «Соціальна педагогіка» показали у цьому питанні більшу освідченість, переважно через вивчений курс навчальних дисциплін: «Педагогіка та психологія сім'ї», «Методика соціально-педагогічної роботи». Серед їхніх відповідей можна виділити такі:

- «Насилля відбувається тоді, коли жінка сама це допускає» (Дарія);

- «Це використання чоловіком жіночої слабкості і знущання над нею» (Оксана);

«Пригнічення морального i завдання шкоди фізичному здоров'ю жінки» (Інна);

- «Чоловік не поважає ні себе, ні жінку, через це він знущається над нею» (Артем);
(Ілля).

До таких небагатослівних, але влучних відповідей, студенти майже всі додали, що проти цього, що говорить про небайдужість молоді до проблеми насилля над жінками в сім'ї.

В Уманському державному педагогічному університеті імені Павла Тичини на факультеті соціальної та психологічної освіти діє Студентська соціальнопсихологічна служба, яка щороку до 25 листопада готує інформаційні плакати про насилля над жінками, роздає білі стрічки в знак підтримки протесту усього світу всіх форм насильства над жінками. Волонтери Служби інформують про насилля над жінками як найпоширеніше порушення прав людини в світі. Про те, що жорстоке поводження забирає більше життів і набагато частіше перетворює жінок у інвалідів, ніж онкологія, малярія, дорожньо-транспортні пригоди та військові дії разом узяті.

Водночас в університеті створено інноваційну структуру, а саме: Гендерний центр, який виступає майданчиком 3 проходження практики студентів - майбутніх соціальних працівників. Мета діяльності Центру є сприяння впровадженню гендерної просвіти шляхом надання науково-практичної допомоги викладачам та студентам щодо впровадження ідей гендерної культури та гендерних підходів у навчально-виховний процес.

У рамках діяльності Центру відбуваються такі заходи: брей-ринг «Гендерні стереотипи; опитування та створення статистичних даних «Ставлення до представників ЛГБТ-спільноти»; науковий флешмоб «Березень місяць жіночої історії»; випуск щомісячника «Гендернй промінь»; діяльність наукового гуртка «Марс-Венера»; акції: «Всенародний день батька!», «Ми проти насильства над жінками», «Будуємо суспільство без насильства», «Здорове суспільство починається зі щасливої та здорової сім’і», «День матері»; фотовиставки: «Мій дбайливий люблячий тато»; «СТОП насильству над жінками»; «Моя мама професіоналка»; тренінгові програми: «Толерантне ставлення до представників ЛГБТспільноти»; «Підготовка молоді до сімейного життя» (квітень-травень).

Так як досліджувані студенти четвертого курсу були активними учасниками цих заходів, проблема насилля над жінками була їм досить знайома і це не склало їм проблем відповісти на запитання «Куди звернутись жінці за допомогою, яка терпить насилля в сім'ї?. Їхні відповіді були такими: «На гарячі лінії психологічної допомоги, в поліцію», «У центри реабілітації», «До соціальної служби», «У центр вторинної допомоги», «Службу у справах сім'ї та молоді» тощо.

У той час, коли основне завдання фахівця із соціальної роботи - бути помічником для кожної родини, яка потребує допомоги, насамперед для сімей, які ризикують потрапити у складні життєві обставини внаслідок втрати роботи членами сім’ї, інвалідності, тяжкого захворювання, насильства над дітьми, розлучення, повернення одного з батьків після відбування покарання в місцях позбавлення волі, неналежного виконання батьківських обов'язків, внаслідок зловживання алкоголем або наркотиками, цікаво було дізнатися: зі скількома жінками, залежними від цих шкідливих для здоров'я звичок, студенти зустрічаються у своєму теперішньому сьогоденні.

Цікавим виявився той факт, що студенти різних курсів відповідали на запитання: «Скількох залежних від алкоголю жінок Ви знаєте? А від наркотиків?» кардинально контрастно. Із опитаних четвертокурсників лише троє студентів написали, що знають таких залежних жінок, причому залежних від алкоголю - більше, ніж від наркотиків. А от студенти-першокурсники майже усі знайомі з жінками таких проблемних категорій. «Залежних від алкоголю - 20, від наркотиків - 3», - пише Владислава $€ . ;$ «Дуже багато!», - пише Руслана Б.; «Багатьох», - підкреслює Вікторія К.

Отже, студентів-першокурсників ці проблеми більше 
хвилюють i, враховуючи їхню вразливу психіку, вони помічають таких жінок більше і турбуються про життя їхніх сімей більше, особливо в яких $є$ діти. А старші студенти - менш вразливі, для них бачити таких жінок звичне явище, яке перейшло в рамки «адаптованості», тому ці студенти дали такі відповіді. Насправді в їхньому оточенні зустрічаються такі категорії жінок, просто вони намагаються їх не помічати.

Загалом, у зазначеному напрямі роботи одним з найголовніших чинників є раннє виявлення сімей, які мають жінку-матір, що зловживає алкоголем або наркотиками та потребує сторонньої допомоги. Мета фахівців із соціальної роботи у профілактиці сімейного неблагополуччя - своєчасно виявити проблему та надати відповідну якісну допомогу. Тож така «адаптованість» до жінок, які мають проблему з алкоголем або наркотиками серед підростаючого покоління - не може існувати, особливо у майбутніх фахівців із соціальної роботи або соціальних педагогів.

Характерним було ще й те, що студенти четвертих курсів спеціальності «Соціальна педагогіка» обізнаніші про соціальні проблеми жінок та можливості їх вирішення через організовану соціально-педагогічну практику у соціальних службах міста, передбачену навчальним процесом спеціальності, та знаннями 3 теоретичних дисциплін їхньої професійно-практичної підготовки.

Окрім того, у рамках виховних годин, ці студенти мали змогу отримувати інформацію про кричущі проблеми суспільства (СНІД та проблеми ВІЛ-інфікованих, у тому числі жінок, наркоманію, алкоголізм, проблеми інклюзіi, розбещеність молоді окремих субкультур, шкідливість татуювань, насилля, які здійснюються в сім'ях над дітьми та жінками).

Це свідчить про те, що соціальним службам потрібно постійно здійснювати діагностичну та профілактичну роботу з населенням, особливо молоддю з соціальних проблем, научати ці проблеми вирішувати, щоб зменшити кількість осіб, які потребуватимуть вторинної та третинної допомоги. Адже фахівець із соціальної роботи, соціальний працівник - особа, яка має відповідну освіту та кваліфікацію, відповідає вимогам, установленим центральним органом виконавчої влади, що забезпечує формування державної політики у сфері соціального захисту населення, проводить оцінку потреб, підготовку договору та індивідуального плану надання соціальних послуг, організовує та надає соціальні послуги, що потребують фахової кваліфікації, а також організовує заходи 3 підтримки вразливих груп населення.

Висновки дослідження $i$ перспективи подальших розвідок иьього напряму. За результатами аналізу міжнародного та вітчизняного гендерного законодавства, з'ясування змісту і спрямованості соціальної роботи 3 жінками, вивчення регіонального досвіду діяльності соціальних служб з жінками, розкриття специфіки підготовки майбутніх соціальних працівників до роботи 3 цією категорією громадян, розроблено рекомендації стосовно підвищення якості надання соціальних послуг жінкам - жертвам домашнього насилля:

1. Вчасно ідентифікувати проблему здійснення насильства в сім'ї щодо жінок (збір первинної інформації, розслідування і складання заяви). Інформація передбачає виявлення ознак насильства за зовнішніми ознаками (наявність слідів побиття, відсутність гігієни і догляду, порушення сну, різка зміна ваги, страх, розгубленість, покора, смуток, небажання проходити огляд лікаря, нестача грошей, невідповідність між можливими і реальними умовами життя). Методи одержання інформації: спостереження, інтерв'ю, бесіда.

2. При потребі втручатись у ситуацію, що здійснюється на основі мультидисциплінарного підходу. Кожен з учасників команди бере участь в обговоренні ситуації, відомостей, оцінці ресурсів, визначенні стратегій роботи і відповідальності кожного із спеціалістів. Фахівець із соціальної роботи, при цьому, здійснює роботу з кон- кретним випадком (добір технік, спрямованих на формування навичок правильної взаємодії; забезпечення підтримки і проведення консультування); координацію діяльності і консультування інших служб; за необхідності - функції координатора роботи мультидисциплінарної команди.

3. Здійснювати корекцію та зміну ситуації (підтримка та активізація членів сім'ї, зміна міжособистісних стосунків, формування навичок правильної взаємодії у сім'ї), здійснюється на основі терапевтичного квадрата, який включає чотири основні групи факторів, необхідних для розуміння ситуації та іії правильної оцінки:

- роль і почуття піклувальника в цій ситуації; ний»)

- природа взаємостосунків «піклувальник - опікува-

- наявність у піклувальника підтримки з боку інших членів сім'і;

- фінансовий стан піклувальника.

4. Проаналізувавши вище перелічені ознаки жінок-жертв сімейного насилля, у корекцію негативних станів потрібно включати:

- соціальну роботу з налагодження зв'язків;

- педагогічну роботу: навчання таким навичкам, як позитивне спілкування (вирішення конфліктів, адекватне висловлювання), адекватне мислення і ставлення до себе, прийняття рішень та психологічного захисту, сприяння підвищенню рівня самооцінки жінки;

- психологічну роботу зі зняття відчуття провини, емоційної та фізичної релаксації.

Перспективою подальших досліджень вважаємо розробку моделі підготовки фахівців у закладах вищої освіти до соціальної роботи з жінками сільської місцевості.

СПИСОК ЛІТЕРАТУРИ:

1. Гендерна дискримінація та насильство щодо жінок. URL http://helsinki.org.ua/index.php?id=1398061293

2. Дмитренко М. І., Тропін М. В., Власов П. О. Попередження насильства у сім'ї: Метод. рекомендаиії. Дніпропетровськ: Дніпропетр. юрид. ін-т МВС України, 2001. 56 с.

3. Доповідь Генерального Секретаря, Проблеми та перспективи досягнення тендерної рівності та розширення прав і можливостей жінок та дівчат у сільських районах. URL: http://undocs.org/E/\%20 CN.6/2018/3

4. Жінки та чоловіки в Украӥні: Статистичний збірник. Київ: Державна служба статистики України. 2015.

5. Закон України «Про попередження насильства в сім'ї» від 15.11.2001 p. № 2789 (з наступними змінами і доповненнями). URL: http://zakon.rada.gov.ua/laws/show/2789-14

6. Кальницька К. О. Особливості соиіально-психологічної роботи з жінками, жертвами насильства в сім'ї. Соиіальна робота як чинник гуманізаиії суспільного буття: Український ВІСНИК № 121148 міжнародний досвід: Тези доповідей та виступів Міжнар. наук.-практ. конф. (м. Чернігів, 3-4 грудня 2010 року): Чернігів : ЧДІЕУ, 2011. C. $114-120$.

7. Комплексне дослідження становища жінок, які проживають у сільській місиевості/Інна Волосевич, Таміла Коноплииька, Тетяна Костюченко, Тамара Мариенюк Киї: ВАITE, 2015. 88 c.

8. Методичний посібник для фахівиів, які впроваджують корекиійні програми для осіб, які вчинили насильство в сім'ї/Укладачі: Мустафаєв Г. Ю., Довгаль I. І. Київ, 2011. 192 с.

9. Нікого не залишити осторонь РОЗШИРЕННЯ ПРАВ I МОЖЛИВОСТЕЙ ЖІНОК ТА ДІВЧАТ 3 СІЛЬСЬКОЇ МІСЦЕВОСТІ \#IWD2018 \#TIMEISNOW. Жінки та дівчата в сільській місиевості. URL: http://www.un.org.ua/images/documents/4301/FACTSHEET\%20 Ukrainian.pdf

10. Уварова О. Права жінок і гендерна рівність в Україні. URL: https://helsinki.org.ua/prava-zhinok-i-henderna-rivnist-v-ukrajini-ouvarova/\# ftn 2

11. Тунтуєва С. В. Сочіально-педагогічна робота з особами, постраждалими від насильства сім '̈̈: навч.-метод. посіб. для студ. вии. навч. закл; Держ. закл. "Луган. нач. ун-т імені Тараса Шевченка». Старобільськ: Вид-во Дз «ЛНУ імені Тараса Шевченка», 2015. 172 с. 